\title{
Short communication: Initial evidence supporting existence of potential rumen epidermal stem and progenitor cells
}

\author{
T. T. Yohe, H. L. M. Tucker, C. L. M. Parsons, A. J. Geiger, R. M. Akers, and K. M. Daniels ${ }^{1}$ \\ Dairy Science Department, Virginia Polytechnic Institute and State University, Blacksburg 24061
}

\begin{abstract}
The bovine rumen epidermis is a keratinized multilayered tissue that experiences persistent cell turnover. Because of this constant cell turnover, epidermal stem cells and their slightly more differentiated daughter cells, epidermal progenitor cells, must exist in the stratum basale of rumen epidermis. To date, these 2 epidermal cell populations and any unique cellular markers they may possess remain completely uncharacterized in the bovine rumen. An important first step in this new research area is the demonstration of the relative abundance and existence of markers for these cells in rumen tissue. A related second step is to document rumen epidermal proliferative responses to an extrinsic signal such as nutrient concentration within the rumen. The objectives of this experiment were to evaluate the extrinsic effect of diet on (1) gene expression of 6 potential rumen epidermal stem or progenitor cell markers and (2) rumen epidermal cell proliferation within the stratum basale. Twelve preweaned Holstein heifers were fed either a restricted diet (R) or an enhanced diet $(\mathrm{EH})$. Animals on $\mathrm{R}$ received a milk replacer (MR) diet fed at $0.44 \mathrm{~kg}$ of powder dry matter $(\mathrm{DM}) / \mathrm{d}(20.9 \%$ crude protein, $29.8 \%$ fat, DM basis) and $\mathrm{EH}$ received $\mathrm{MR}$ at $1.08 \mathrm{~kg}$ of powder dry matter/d (28.9\% crude protein, $26.2 \%$ fat, DM basis). All calves had access to a $20 \%$ crude protein starter and were weaned during wk 7 of the experiment. Lifetime DM intake was $0.73 \mathrm{~kg}$ of DM/calf per day for R $(5.88 \mathrm{Mcal}$ of net energy/calf per day) and $1.26 \mathrm{~kg}$ of DM/calf per day for $\mathrm{EH}$ (10.68 Mcal of net energy/calf per day). Twenty-four hours before slaughter heifers received an intravenous dose of 5-bromo-2'-deoxyuridine to label proliferating cells. Heifers were slaughtered at 8 wk of age, and rumen samples from the ventral sac region were obtained and stored in RNA preservative and processed for routine histology. Quantitative real-time reverse transcriptase PCR was used to analyze relative abundance of genes.
\end{abstract}

Received January 11, 2016.

Accepted May 27, 2016.

${ }^{1}$ Corresponding author: danielsk@vt.edu
Candidate genes for markers of epidermal stem and progenitor cells were $\beta 1$-integrin (ITGB1), tumor protein p63 (TP63), keratin-14 (KRT14), Notch-1 (NOTCH1), Leu-rich repeat-containing $\mathrm{G}$ protein-coupled receptor 5-expressing (LGR5), and musashi-1 (MSI1). All genes were detected in the rumen tissue; ITGB1 was increased in EH compared with R. 5-Bromo-2'-deoxyuridine immunohistochemistry revealed that both $\mathrm{R}$ and $\mathrm{EH}$ rumen tissue had proliferating cells within the stratum basale of the rumen epidermis at the time of analysis. The EH diet resulted in an additive effect on cell proliferation. The percentage of cells in the stratum basale synthesizing DNA in preparation for mitosis nearly doubled $(23.8 \pm 2.4 \%$ for $\mathrm{EH}$ vs. $14.7 \pm 2.0 \%$ for $\mathrm{R})$ compared with calves fed R. This work represents the first attempt at characterizing rumen epidermal stem and progenitor cells. We demonstrated the relative abundance and existence of potential markers in rumen tissue and showed a rumen epidermal proliferative response to the extrinsic stimulus of nutrient concentration in the form of diet.

Key words: dairy calf, cell proliferation, mitosis, epidermis, epithelium

\section{Short Communication}

The epidermis of bovine rumen is a multilayered keratinized, stratified squamous epithelium. It is situated on top of the dermis, hence its name. The rumen epidermis is the first line of defense against microbial infiltration and also the first site for nutrient absorption; it therefore has barrier and absorptive functions. Rumen epithelium is composed of 4 strata, plus an outer layer of keratin and is collectively called the epidermis. Keratin is the most superficial layer, followed by the stratum corneum, stratum granulosum, stratum spinosum, and stratum basale. A basement membrane is situated below the stratum basale, followed by the dermis, which contains blood vessels (see Figure 2). The rumen epidermis is dynamic and must be maintained throughout life. Epidermal homeostasis requires cellular proliferation and differentiation events that originate in the stratum basale (Figure 2). From studies with other epidermal tissues, it is known that 
physiological cues induce cells in the stratum basale to detach from the underlying basement membrane, withdraw from the cell cycle, and begin the process of terminal differentiation and migration to the surface (Zouboulis et al., 2008). These committed cells traverse through the epidermal layers before being shed from the epidermal surface as cornified cells (Figure 2; Lavker and Matoltsy, 1970). In rumen epidermis, as with other types of epidermis, cellular death and loss through cornification occurs continuously. Thus, new differentiated cells must be generated throughout life to replenish lost cells. Because of this persistent epidermal cell turnover, it is hypothesized that epidermal stem cells and their slightly more differentiated daughter cells, epidermal progenitor cells (also known as transitamplifying cells), must exist in the stratum basale of the rumen epidermis. Further, to function as true stem and progenitor cells, these candidate cells must be able to respond to extrinsic stimuli, such as nutrient concentration. Last, these cell populations must have unique cellular markers that distinguish them from other epidermal cells.

To date, these 2 epidermal cell populations and any unique cellular markers they may possess remain poorly understood in bovine rumen. Over the years, rumen epidermal cell proliferation has been quantified in numerous ways. Some methods include quantification of the proportion of stratum basale cells: with mitotic figures (Sakata and Tamate, 1978; Shen et al., 2004; Malhi et al., 2013), labeled with tritiated thymidine (Goodlad, 1981; Ohwada et al., 1984; Neogrády et al., 1989), Ki-67 labeled (Mentschel et al., 2001), or 5-bromo-2'-deoxyuridine (BrdU) and Ki-67 labeled cells (Baldwin et al., 2004), but an attempt has never been made to link these proliferation events to the presence of potential stem and progenitor cells. An important first step in this new research area is the demonstration of abundance and existence of these potential markers in rumen tissue. A related second step is to document rumen epidermal proliferative responses to the extrinsic signal of nutrient concentration within the rumen itself.

Regarding the existence of rumen epidermal stem and progenitor cell markers, $\beta 1$-integrin (ITGB1), tumor protein p63 (TP63), keratin-14 (KRT14), and Notch-1 (NOTCH1) are documented epidermal stem and progenitor cell markers in other species and organs (Zouboulis et al., 2008; Ambler and Maatta, 2009; Eckhart et al., 2013). Also, Leu-rich repeat-containing G protein-coupled receptor 5-expressing (LGR5), and musashi-1 (MSI1), a RNA-binding protein, are commonly accepted intestinal stem cell markers in other animals (Barker, 2014; Clevers et al., 2014; Tan and Barker, 2014). Because the rumen has properties that are characteristic of both epidermis (barrier function) and intestine (nutrient absorptive function), we rationalized that presence of these markers may indicate not only the existence of bovine rumen epidermal stem or progenitor cells, but also that these markers are potentially specific for rumen epidermal stem or progenitor cells.

The primary objective of this experiment was to evaluate the extrinsic effect of diet on (1) gene expression of 6 potential rumen epidermal stem or progenitor cell markers and (2) rumen epidermal cell proliferation within the stratum basale.

The Virginia Tech (VT) Animal Care and Use Committee approved the live animal experimental portion of this work (protocol \#14-045-DASC). Twelve Holstein heifers were used in an experiment that lasted approximately $2 \mathrm{mo}$; they were part of a larger experiment that dealt with effects of diet on mammary gland growth and full experimental details are reported (Geiger et al., 2016). Briefly, the 12 heifers used here were purchased from a single commercial dairy producer located $\sim 145$ $\mathrm{km}$ from VT; at VT, heifers were individually housed in outdoor hutches on crushed rock without bedding. Heifers had ad libitum access to water. The experimental unit was heifer. Heifers were approximately $1 \mathrm{wk}$ old $(5.3 \pm 2.3 \mathrm{~d}$; mean $\pm \mathrm{SD})$ at the time of arrival to $\mathrm{VT}$, had serum total protein $\geq 5.5 \mathrm{~g} / \mathrm{dL}$, and weighed $40.4 \pm 4.6 \mathrm{~kg}$ (mean $\pm \mathrm{SD}$ ). Heifers used here were in the original treatment groups of restricted $(\mathbf{R})$ or enhanced (EH), which is in reference to the treatment diet (Geiger et al., 2016). In the original experiment, one heifer on EH died within $48 \mathrm{~h}$ of arrival to VT and was not replaced. The final animal numbers were $\mathrm{R}, \mathrm{n}$ $=6$, and $\mathrm{EH}, \mathrm{n}=5$.

Heifers on $\mathrm{R}$ received fewer nutrients through milk replacer (MR) than heifers on EH. The MR fed to R heifers was $20.9 \% \mathrm{CP}$ and $19.8 \%$ fat (DM basis), offered at $0.43 \mathrm{~kg}$ of MR powder/heifer per d (DM basis). The MR fed to EH heifers was $28.9 \%$ CP, $26.2 \%$ fat (DM basis), offered at $1.08 \mathrm{~kg}$ of MR powder/heifer per d (DM basis). Both MR were reconstituted to $13 \%$ solids and fed twice daily in equal portions at 0600 and $1700 \mathrm{~h}$. During the eighth week of the trial, heifers were weaned from MR by removing one daily feeding. The weaning process lasted $7 \mathrm{~d}$. Throughout the experiment, heifers had access to a $25.6 \% \mathrm{CP}, 4.0 \%$ fat, and 19.8\% NDF (DM basis) texturized calf starter. The amount of calf starter offered per calf was adjusted daily so that starter intake of $\mathrm{R}$ approximated that of EH (described in Geiger et al., 2016). Refusals of MR and starter, if any, were recorded daily and are reported elsewhere (Geiger et al., 2016). Likewise, heifer BW were obtained weekly and are summarized in Geiger et al. (2016). 
Approximately $24 \mathrm{~h}$ before slaughter, which occurred at $62 \pm 2 \mathrm{~d}$ of age (mean $\pm \mathrm{SD}$ ), each heifer was administered a single intravenous injection of BrdU at $5 \mathrm{mg} /$ $\mathrm{kg}$ of BW; sterile BrdU solution was prepared according to Daniels et al. (2009). Bromodeoxyuridine is a thymidine analog and incorporates into newly synthesized DNA strands, thus marking actively proliferating cells.

Feed was withheld in the $12 \mathrm{~h}$ before slaughter. Heifers were euthanized via intravenous administration of a commercial phenobarbital solution (Fatal-Plus, 10 $\mathrm{mg} / \mathrm{kg}$ of BW, Vortech Pharmaceuticals, Dearborn, MI), followed by immediate exsanguination. The entire gastro-intestinal tract was then ligated, removed, and weighed full; forestomach organ measurements are summarized elsewhere (Geiger et al., 2016). Rumen samples intended for gene expression and immunohistochemistry analyses were obtained exclusively from the ventral sac of each emptied and washed rumen.

Samples for rumen gene expression were processed as follows. First, a punch biopsy tool with an internal diameter of $2.54 \mathrm{~cm}$ was used to obtain full-thickness rumen biopsy samples (epidermis + dermis + muscle layers) from the ventral sac within each washed rumen. Forceps were then used to peel the muscle layers away from the epidermis + dermis; the muscle-containing portion was discarded and the epidermis + dermis portion of each sample was placed in tubes containing an RNA preservative (700 g of ammonium sulfate, $40 \mathrm{~mL}$ of $0.5 M$ EDTA at $\mathrm{pH} 8$, and $25 \mathrm{~mL}$ of $1 M$ sodium citrate in $935 \mathrm{~mL}$ of purified water and brought to $\mathrm{pH} 5.2$ using $\sim 1.3 \mathrm{~mL}$ of sulfuric acid and $\sim 330 \mu \mathrm{L}$ of $10 M$ sodium hydroxide) and stored on wet ice until permanent storage in a $-70^{\circ} \mathrm{C}$ freezer later that same day. This sample collection technique ensured that only rumen papillae (dermis + epidermis) were submitted for later analyses.

Total RNA was extracted using the Qiagen RNeasy Plus Mini Kit (Qiagen, Valencia, CA). Approximately $30 \mathrm{mg}$ of rumen epidermal tissue was taken out of the RNA preservative and placed into $600 \mu \mathrm{L}$ of lysis buffer $(10 \mu \mathrm{L}$ of $\beta$-mercaptoethanol in every $1 \mathrm{~mL}$ of buffer RLT Plus) in a 14-mL Falcon tube (Fisher Scientific, Waltham, MA). Each sample was homogenized using a Bio-Gen PRO200 homogenizer (Pro Scientific, Oxford, CT) at its top speed for $30 \mathrm{~s}$ and placed on ice. After centrifugation at $20,817 \times g$ for $3 \mathrm{~min}$ at $23^{\circ} \mathrm{C}$, supernatant was then placed in a genomic DNA eliminator column and centrifuged for 10,621 $\times g$ for $30 \mathrm{~s}$ at $23^{\circ} \mathrm{C}$. The flow-through was then processed using an RNeasy Plus mini kit. The RNA purity and quantity were determined using a NanoDrop ND-1000 spectrophotometer (NanoDrop Technologies, Rockland, DE). Furthermore, RNA quality was determined using the Agilent 2100 Bioanalyzer (Agilent Technologies, Santa
Clara, CA) with an average RNA integrity number of $6.87 \pm 0.13$ (SEM).

Single-stranded cDNA was synthesized from each RNA sample according to the method of Swank et al. (2013). Each real-time quantitative (q)PCR assay was performed on all samples in duplicate, with each reaction mixture $(20 \mu \mathrm{L})$ containing $0.5 \mu \mathrm{L}$ each forward and reverse primer, $10 \mu \mathrm{L}$ of SYBR Green Supermix (Bio-Rad, Hercules, CA), $8 \mu \mathrm{L}$ of RNase/DNase free water, and $1 \mu \mathrm{L}$ of cDNA (1:1 stock). The qPCR assays were performed using an iQ5 Multicolor Real Time PCR Detection System (Bio-Rad) with the following cycling conditions: $95^{\circ} \mathrm{C}$ for $3 \mathrm{~min}$; 45 repeating cycles of $94^{\circ} \mathrm{C}$ for $15 \mathrm{~s}$ (denaturation), respective temperature (Table 1) for a set of primers for $30 \mathrm{~s}$ (annealing), and $72^{\circ} \mathrm{C}$ for $30 \mathrm{~s}$ (extension); $95.0^{\circ} \mathrm{C}$ for $2 \mathrm{~min}, 55.0^{\circ} \mathrm{C}$ for $30 \mathrm{~s}$, and then a temperature increase at $1.0^{\circ} \mathrm{C}$ increments to $95.0^{\circ} \mathrm{C}$ (melting curve). Each assay included a no-template control and a no-reverse-transcriptase control, with the no-template control receiving $1 \mu \mathrm{L}$ of RNase/DNase free water instead of cDNA, whereas the no-reverse-transcriptase control received a $1-\mu \mathrm{L}$ sample of the reverse transcription product to which no reverse transcriptase was added. The qPCR was repeated when the resulting intra-assay coefficient of variation was greater than $5 \%$.

Primers were designed with Primer3 (v. 0.4.0; http:// bioinfo.ut.ee/primer3-0.4.0/; Rozen and Skaletsky, 2000) for all genes used. Validation of primers consisted of 2 steps. Melting curve analyses were performed after each qPCR assay to determine whether primer dimers or genomic DNA contamination were present during the assay. Also, product size variation using gel electrophoresis was performed after each qPCR assay. For product size variation, representative samples of qPCR products for each primer pair were electrophoresed on a $3.5 \%$ agarose gel to confirm the expected size of each amplicon. All qPCR products were visualized as single bands that corresponded with predicted product size (data not shown).

Target genes of interest were normalized to the geometric mean of ubiquitously expressed transcript $(\boldsymbol{U} \boldsymbol{X} \boldsymbol{T})$, ribosomal protein S9 ( $\boldsymbol{R P S 9})$, ribosomal protein S15 (RPS15), and ribosomal protein S26 (RPS26; target gene $\mathrm{Ct}$ - reference genes $\mathrm{Ct}=\Delta \mathrm{Ct}$; Vandesompele et al., 2002). The $\mathrm{Ct}$ values for $U X T$, RPS9, RPS15, and RPS26 were evaluated using algorithms used in the GeNorm software for analysis of qPCR data to create M stability values for each reference gene (Hellemans et al., 2007). The M stability values calculated were 0.095 (UXT), 0.101 (RPS9), 0.086 (RPS15), and 0.135 (RPS26). A lower M stability value indicates higher stability; Pérez et al. (2008) deemed M stability values below 1.5 as acceptable, so for this study UXT, RPS9, 
RPS15, and RPS26 were deemed acceptable reference genes. Delta $\mathrm{Ct}$ data were transformed to $2^{(-\Delta \mathrm{Ct})}$ to represent fold differences relative to the reference genes (Velayudhan et al., 2008). Raw data were not normally distributed (Shapiro Wilk's test) so all genes were then transformed by the natural log of the $\Delta \mathrm{Ct}$ value before statistical analysis. Data were omitted for one $\mathrm{R}$ calf due to poor sample quality, which makes final numbers for qPCR analysis: $\mathrm{R}, \mathrm{n}=5$, and $\mathrm{EH}, \mathrm{n}=5$.

Full-length rumen tissue (epidermis + dermis + muscle layers) from each heifer was fixed overnight in $10 \%$ neutral buffered formalin. Samples were then routinely processed, embedded in paraffin, cut to 5 - $\mu \mathrm{m}$ thickness on a microtome, and mounted onto positively charged glass microscope slides (Yohe et al., 2015).

The BrdU immunohistochemistry was performed as previously reported (Daniels et al., 2009), with the following noted modifications. The primary antibody was mouse monoclonal anti-bromodeoxyuridine, clone AH4H7-1 (Millipore, catalog \# MAB3424; used at 1:100 dilution). The secondary antibody was Alexa Fluor 488 goat anti-mouse $\operatorname{IgG}\left(\mathrm{H}^{+} \mathrm{L}\right.$, catalog \#A11029 used at 1:200 dilution; Invitrogen, Carlsbad, CA). Coverslips were mounted with SlowFade Gold with DAPI (Invitrogen). Cells positive for $\mathrm{BrdU}$ in the stratum basale layer of the rumen epidermis were quantified in the following manner. Digital images were acquired at $40 \times$ magnification using a Nikon Eclipse E600 epi- fluorescence microscope fitted with a Nuance FX Multispectral Imaging System (Perkin-Elmer, Waltham, MA). Captured image files were unmixed to generate monochromatic images from the blue DAPI and green FITC channels, to detect any cell with a nucleus and BrdU-positive cells, respectively. Unmixed images were opened with and analyzed in Image-Pro Plus version 7.0 (Media Cybernetics, Rockville, MD). Pseudo-colored composite images of DAPI labeled (blue) and Alexa Fluor 488 labeled nuclei (green) were generated. These pseudo-colored composite images were individually opened; line segments were created using a freehand drawing tool that followed the contour of the stratum basale. The DAPI-labeled nuclei in the stratum basale were manually marked and counted. In addition, nuclei dual labeled with DAPI and Alexa Fluor 488 in the stratum basale were also counted. Ten images were obtained per animal with an average of 900 basale cells counted per animal. The BrdU labeling index within the stratum basale is defined as the number of duallabeled cells divided by the number of all counted cells, multiplied by 100. An example of BrdU staining is in Figure 2. Data were omitted for one EH calf due to poor sample quality, which makes the final numbers for immunohistochemistry analysis: $\mathrm{R}, \mathrm{n}=6$, and $\mathrm{EH}$, $\mathrm{n}=4$.

Variance analyses for gene expression and BrdU data were performed using SAS (version 9.2, SAS Institute

Table 1. PCR primers used to evaluate gene expression in rumen epidermal tissue

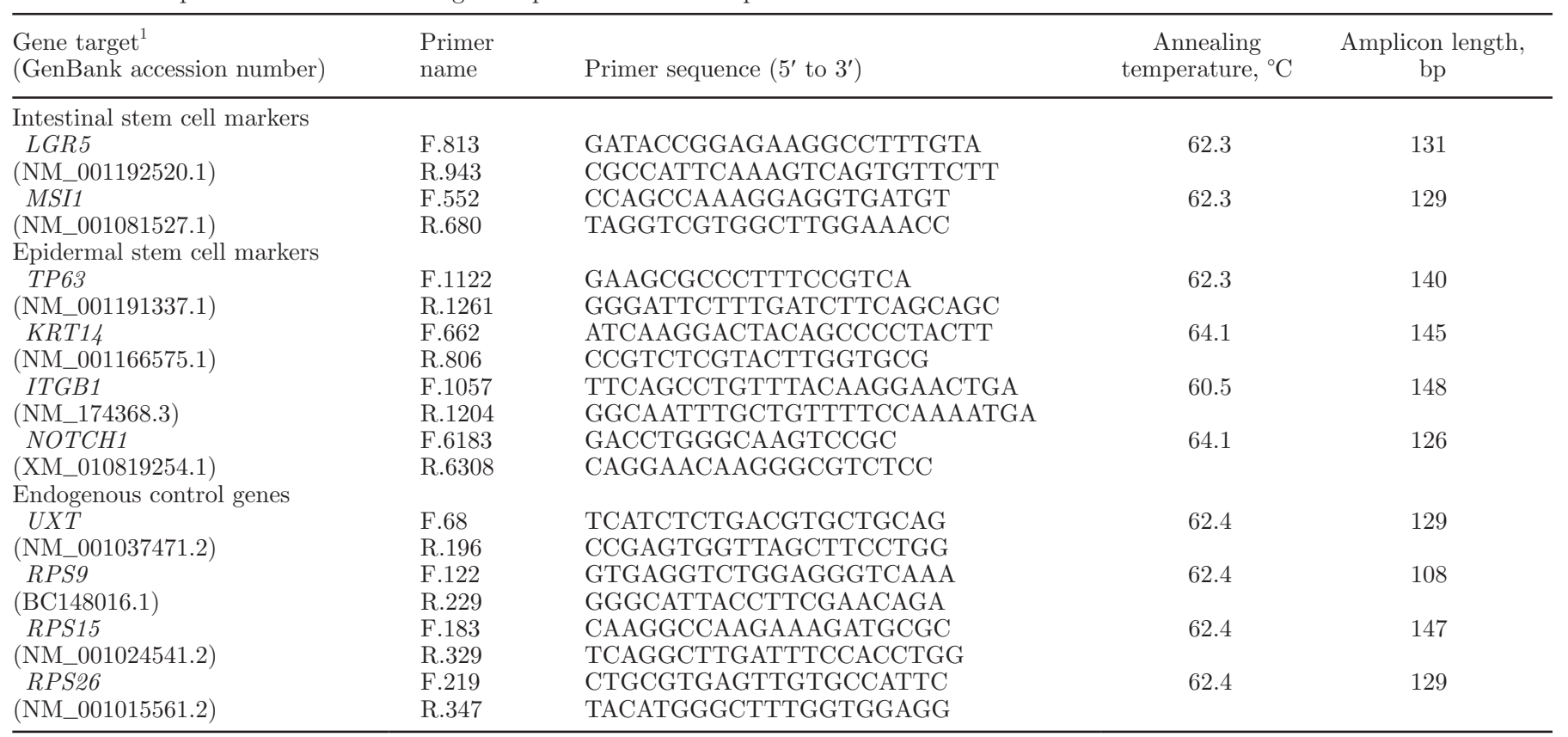

${ }^{1} L G R 5=$ leucine-rich repeat containing $\mathrm{G}$ protein-coupled receptor 5; MSH1 = Musashi RNA-binding protein 1: TP63 = tumor protein p63; KRT14 = keratin 14; ITGB1 = integrin, $\beta 1 ;$ NOTCH1 $=$ Notch $1 ; U X T=$ ubiquitously expressed transcript; RPS9= ribosomal protein S9; $R P S 15=$ ribosomal protein S15; RPS26 = ribosomal protein S26. 
Inc., Cary, NC) with a mixed model that included the fixed effect of diet and the random effect of heifer within diet. Rumen epidermal gene data were transformed to natural $\log$ values before statistical analysis to satisfy ANOVA requirements for normality. Data were backtransformed to generate Figure 1. Significance was declared when $P \leq 0.05$. Least squares means \pm standard errors of the mean are reported for these data.

Calf growth data are reported elsewhere (Geiger et al., 2016). Calves assigned to EH grew at a faster rate than heifers assigned to R; this was an intended effect of the treatments as total DMI was different by design. Lifetime DMI was $0.73 \mathrm{~kg}$ of DM/calf per d for R (n $=6)$ and $1.26 \mathrm{~kg}$ of $\mathrm{DM} /$ calf per $\mathrm{d}$ for $\mathrm{EH}(\mathrm{n}=5)$. Lifetime net energy intake was $5.88 \mathrm{Mcal} / \mathrm{d}$ and 10.68 $\mathrm{Mcal} / \mathrm{d}$ for $\mathrm{R}$ and $\mathrm{EH}$ calves, respectively. Calf $\mathrm{BW}$ were not different at the beginning of the trial, but beginning in the second week of the trial, $\mathrm{EH}$ weighed more than R. At the end of the trial, EH weighed 73.0 $\pm 0.8 \mathrm{~kg}($ mean $\pm \mathrm{SD})$, whereas $\mathrm{R}$ weighed $62 \pm 0.8 \mathrm{~kg}$ $($ mean $\pm \mathrm{SD})$.

The research problem, as we defined it, was that rumen epidermal stem and progenitor cell populations and any unique cellular markers they may possess are uncharacterized in bovine rumen. An important first step in this new research area is demonstration of abundance/existence of these potential markers in rumen tissue. We met this goal by doing qPCR experiments and showed that all 6 genes (LGR5, MSI1, TP63, KRT14, ITGB1, and NOTCH1) are expressed in ruminal papillae (full-thickness rumen epidermis + dermis; Figure 1). Further, in decreasing order and regardless of diet, the overall abundance of these genes was KRT14 > ITGB1 > TP63>NOTCH1>LGR5 $>$ MSI1 (Figure 1). This pattern is perhaps reflective of the rumen epidermis being more similar in structure to the skin epidermis as opposed to the intestine, as was discussed in the Introduction. Also, we found that feeding a high ADG diet (EH) from wk 1 to 9 of age increased expression of ITGB1 measured at wk 9 after a $12 \mathrm{~h}$ fast (Figure 1). This potentially demonstrates a response to the extrinsic stimulus of nutrient concentration and is something that stem and progenitor cells must be able to do. We caution that when interpreting these data, it must be remembered that the absence of a dietary effect at the gene level does not preclude effects measured at the protein level. Likewise, gene difference in ITGB1 abundance may not equate to differences at the protein level. Also, it is worth reiterating that these heifers underwent a $12 \mathrm{~h}$ fast before slaughter; this may have affected gene expression. However, all animals were subjected to the same conditions so comparison should still be valid. Our documentation of the existence of all 6 of these gene transcripts in bovine epidermis is

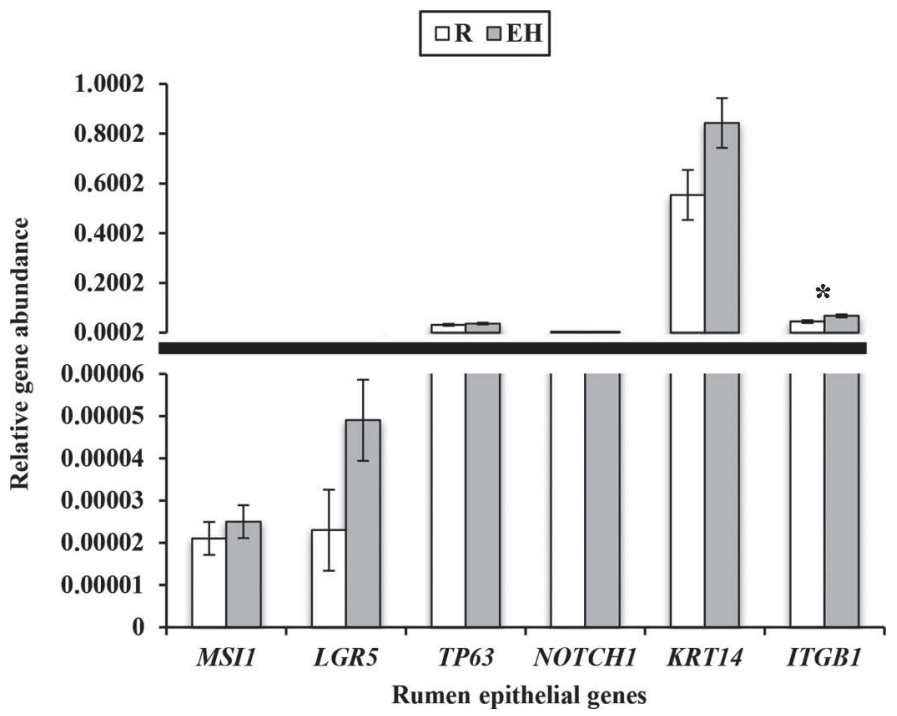

Figure 1. Real-time quantitative (q)PCR was used to show that known intestinal stem cell genes musashi-1 (MSI1), and leucine-rich repeat containing $\mathrm{G}$ protein-coupled receptor 5 (LGR5), along with known epidermal stem and progenitor cell genes p63, NOTCH-1, keratin-14 (KRT14), and B-1 integrin (ITGB1) are all expressed in bovine rumen epidermis + dermis of 62 -d-old dairy calves. Calves were fed either a restricted $\operatorname{diet}(\mathrm{R} ; \mathrm{n}=5)$ or an enhanced $\operatorname{diet}(\mathrm{EH} ; \mathrm{n}=5)$. Calves on $\mathrm{R}$ received a milk replacer (MR) diet fed at $0.44 \mathrm{~kg}$ of powder DM/d (20.9\% CP, 29.8\% fat, DM basis) and EH received MR at $1.08 \mathrm{~kg}$ of powder DM/d (28.9\% CP, $26.2 \%$ fat, DM basis). All calves had access to a $20 \% \mathrm{CP}$ starter. Lifetime DMI was $0.73 \mathrm{~kg}$ of DM/calf per d for R (5.88 Mcal of net energy/calf per d) and $1.26 \mathrm{~kg}$ of DM/ calf per d for EH (10.68 Mcal of net energy/calf per d). ${ }^{*} P<0.05$. Data are reported as LSM $\pm \mathrm{SEM}$.

exciting. However, we are not yet sure of the protein localization of these 6 gene transcripts within the fullthickness rumen epidermis + dermis. Further, we acknowledge that some of the signal obtained through our qPCR analyses may have originated from the dermis or supra-basale cell layers of the rumen epidermis. We can definitely say that none of the detected signal arose from smooth muscle because that portion of rumen tissue was dissected and discarded at sample collection. Going forward, these 6 markers will only remain in the stem and progenitor cell marker candidate pool if we show them to be present exclusively in the stratum basale of the rumen epidermis.

The second research problem we addressed was to evaluate the extrinsic effect of diet on rumen epidermal cell proliferation within the stratum basale. All animals tested had BrdU-positive cells located within the stratum basale of the rumen epidermis, signifying active epidermal cell proliferation within $24 \mathrm{~h}$ of slaughter (includes $12 \mathrm{~h}$ of fasting). This was expected because epidermal tissues experience high cell turnover and rely on cell proliferation to help maintain the tissue. Feeding calves a high ADG diet (EH) resulted in an additive effect on cell proliferation. The percentage of cells in 
the stratum basale synthesizing DNA in preparation for mitosis almost doubled $(23.8 \pm 2.4 \%$ for $\mathrm{EH}$ vs. $14.7 \pm 2.0 \%$ for $\mathrm{R}$ ) compared with calves fed a diet that supported a low ADG (Figure 2). These data build on knowledge obtained in previous studies (Sakata and Tamate, 1978; Goodlad, 1981; Sakata and Yajima, 1984) and help provide a link between activity of stem and progenitor cells (i.e., rumen cell proliferation) and diet. The percentages of proliferating rumen epidermal cells in these growing heifers are numerically higher, but in general agreement with, similar measurements in rumens of other growing dairy calves (Mentschel et al., 2001), growing beef steers (Baldwin and McLeod, 2000), and lactating dairy cows (Baldwin et al., 2004).

In closing, we showed that 6 candidate epidermal stem or progenitor cell markers (LGR5, MSI1, TP63, KRT14, ITGB1, and NOTCH1) exist at the gene level in full-thickness bovine rumen epidermis + dermis. We also showed that the relative gene abundance of one of these (ITGB1) was increased in animals fed a high ADG diet. Last, we presented that in 8-wk-old dairy heifers, feeding a high ADG diet compared with a low ADG diet had an additive effect on rumen epidermal cell proliferation and this occurred exclusively in the stratum basale of the epidermis. Rumen epidermal proliferation and differentiation events are likely coordinated with VFA absorption and might therefore affect nutrient utilization and feed efficiency. If true, better understanding of these regulated processes represent a likely point of animal management intervention that may improve whole animal feed efficiency. Continued work in this new area of rumen epidermal stem and progenitor cells, by our research group and others, will add to our knowledge of how the structure of the
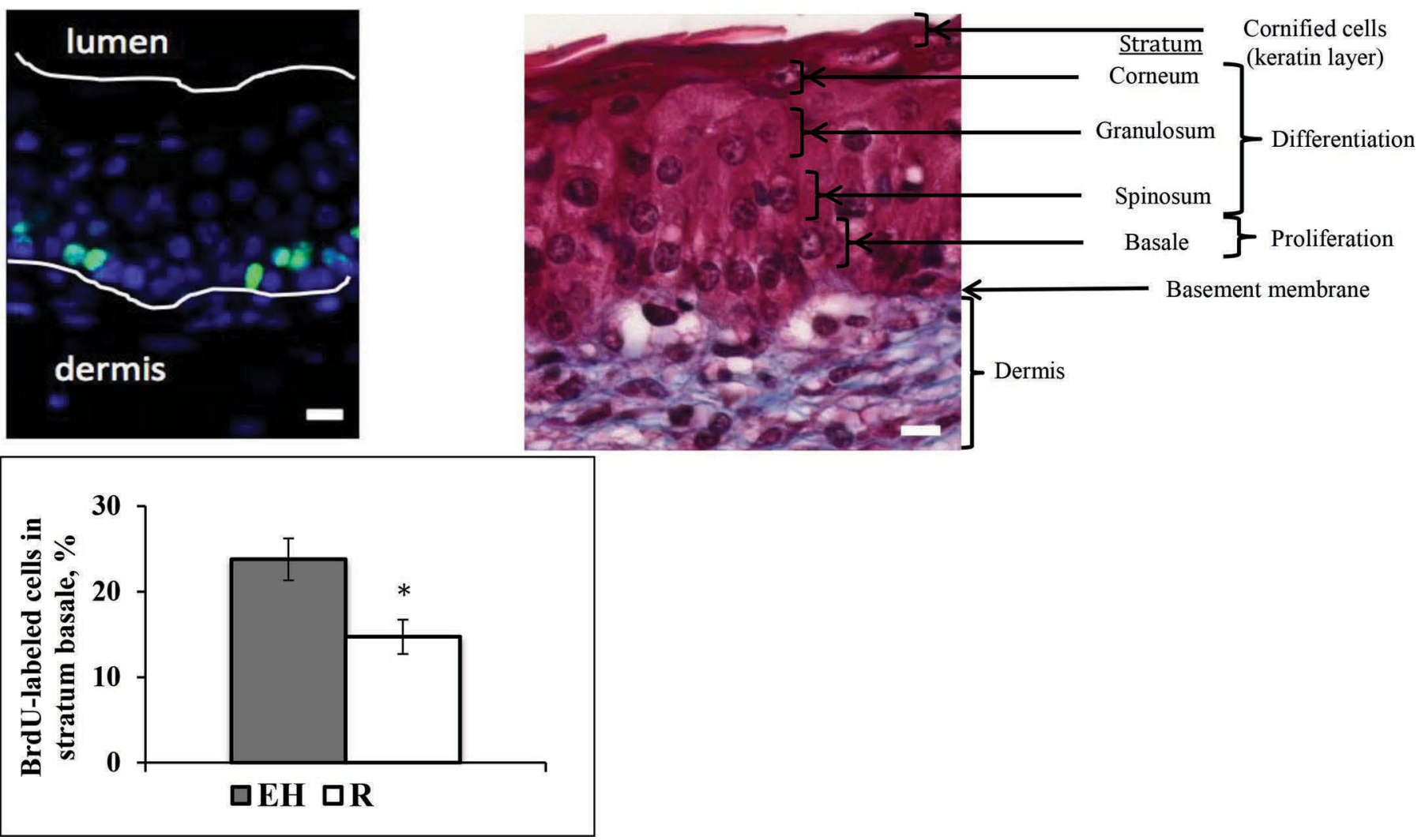

Figure 2. The thymidine analog 5-bromo-2'-deoxyuridine (BrdU) can be used to label DNA. Here, BrdU was injected 24 h before slaughter and labeled all cells undergoing DNA synthesis in the S phase of the cell cycle. The top left panel shows that DNA synthesis in the rumen epidermis (bounded by white) occurs exclusively in the stratum basale $[$ BrdU = light gray (green); DAPI nuclear counterstain = dark gray (blue)]. The top right panel is rumen tissue stained with Masson's trichrome provided for histological comparison (trichrome staining methods described in Yohe et al., 2015) with the organization of the proliferative and differentiated cell compartments of rumen epidermis defined. Scale bars are $10 \mu \mathrm{m}$. The bottom panel shows that rumen epidermal DNA synthesis can be affected by diet in 62-d-old calves. Calves were fed either a restricted diet $(\mathrm{R} ; \mathrm{n}=6)$ or an enhanced diet $(\mathrm{EH} ; \mathrm{n}=4)$. Calves on $\mathrm{R}$ received a milk replacer $(\mathrm{MR})$ diet fed at $0.44 \mathrm{~kg}$ of powder $\mathrm{DM} / \mathrm{d}$ (20.9\% CP, $29.8 \%$ fat, DM basis) and EH received MR at $1.08 \mathrm{~kg}$ of powder DM/d (28.9\% CP, 26.2\% fat, DM basis). All calves had access to a $20 \% \mathrm{CP}$ starter. Lifetime DMI was $0.73 \mathrm{~kg}$ of DM/calf per d for R (5.88 Mcal of net energy/calf per d) and $1.26 \mathrm{~kg}$ of DM/calf per d for EH (10.68 Mcal of net energy/calf per d). ${ }^{*} P=0.05$. Data are reported as LSM \pm SEM. Color version available online. 
rumen epidermis is maintained, how the rumen epidermis functions as a microbial barrier but also as a point of absorption for VFA, and how various nutrition programs affect ruminant nutrient utilization and feed efficiency.

\section{ACKNOWLEDGMENTS}

The animal portion of this work was supported by a National Research Initiative Competitive Grant no. 2016-67015-24275, "Impact of Pre-Weaning Nutrition on Endocrine Induction of Mammary Development in Dairy Heifers" to R. M. Akers from the USDA National Institute of Food and Agriculture (Washington, DC) and USDA award no. 2016-67011-24703, a pre-doctoral fellowship awarded to A. J. Geiger from the USDAFood, Agriculture, Natural Resources and Human Sciences Education and Literacy Initiative competitive grants program.

\section{REFERENCES}

Ambler, C. A., and A. Maatta. 2009. Epidermal stem cells: Location, potential and contribution to cancer. J. Pathol. 217:206-216.

Baldwin, R. L. 6th, and K. R. McLeod. 2000. Effects of diet forage ratio and metabolizable energy intake on isolated rumen epithelial cell metabolism in vitro. J. Anim. Sci. 78:771-783.

Baldwin, R. L. 6th, K. R. McLeod, and A. V. Capuco. 2004. Visceral tissue growth and proliferation during the bovine lactation cycle. J. Dairy Sci. 87:2977-2986.

Barker, N. 2014. Adult intestinal stem cells: Critical drivers of epithelial homeostasis and regeneration. Nat. Rev. Mol. Cell Biol. $15: 19-33$.

Clevers, H., K. M. Loh, and R. Nusse. 2014. Stem cell signaling. An integral program for tissue renewal and regeneration: Wnt signaling and stem cell control. Science 346:1248012.

Daniels, K. M., A. V. Capuco, M. L. McGilliard, R. E. James, and R. M. Akers. 2009. Effects of milk replacer formulation on measures of mammary growth and composition in Holstein heifers. J. Dairy Sci. 92:5937-5950.

Eckhart, L., S. Lippens, E. Tschachler, and W. Declercq. 2013. Cell death by cornification. Biochim. Biophys. Acta 1833:3471-3480.

Geiger, A. J., C. L. M. Parsons, R. E. James, and R. M. Akers. 2016. Growth, intake, and health of Holstein heifer calves fed an enhanced preweaning diet with or without postweaning exogenous estrogen. J. Dairy Sci. 99:3995-4004.

Goodlad, R. A. 1981. Some effects of diet on the mitotic index and the cell cycle of the ruminal epithelium of sheep. Q. J. Exp. Physiol. $66: 487-499$.

Hellemans, J., G. Mortier, A. De Paepe, F. Speleman, and J. Vandesompele. 2007. qBase relative quantification framework and software for management and automated analysis of real-time quantitative PCR data. Genome Biol. 8:R19.
Lavker, R. M., and A. G. Matoltsy. 1970. Formation of horny cells: The fate of cell organelles and differentiation products in ruminal epithelium. J. Cell Biol. 44:501-512.

Malhi, M., G. Hongbing, L. Yao, J. R. Aschenbach, G. Gaebel, and Z. Shen. 2013. Increased papillae growth and enhanced short-chain fatty acid absorption in the rumen of goats are associated with transient increased in cyclin D1 expression after ruminal butyrate infusion. J. Dairy Sci. 96:7603-7616.

Mentschel, J., R. Leiser, C. Mulling, C. Pfarrer, and R. Claus. 2001. Butyric acid stimulates rumen mucosa development in the calf mainly by a reduction of apoptosis. Arch. Tierernahr. 55:85-102.

Neogrády, S., P. Galfi, F. Kutas, and T. Sakata. 1989. The effects of butyrate and glucagon on the proliferation of ruminal epithelial cells in culture. Vet. Res. Commun. 13:27-29.

Ohwada, S., Y. Shiomura, and H. Tamate. 1984. A stathmokinetic study on the ruminal epithelium of sheep. Vet. Res. Commun. 8:203-209.

Pérez, R., I. Tupac-Yupanqui, and S. Dunner. 2008. Evaluation of suitable reference genes for gene expression studies in bovine muscular tissue. BMC Mol. Biol. 9:79-84.

Rozen, S., and H. J. Skaletsky. 2000. Primer3 on the WWW for general users and for biologist programmers. Pages 365-386 in Bioinformatics Methods and Protocols: Methods in Molecular Biology. S. Krawetz and S. Misener, ed. Humana Press, Totowa, NJ.

Sakata, T., and H. Tamate. 1978. Rumen epithelial cell proliferation accelerated by rapid increase in intraruminal butyrate. J. Dairy Sci. 61:1109-1113.

Sakata, T., and T. Yajima. 1984. Influence of short chain fatty acids on the epithelial cell division of digestive tract. Q. J. Exp. Physiol. 69:639-648.

Shen, Z., H. M. Seyfert, B. Loehrke, F. Schneider, R. Zitnan, A. Chudy, S. Kuhla, H. M. Hammon, J. W. Blum, H. Martens, H. Hagemeister, and J. Voigt. 2004. An energy-rich diet causes rumen papillae proliferation associated with more IGF type 1 receptors and increased plasma IGF-1 concentrations in young goats. J. Nutr. 134:11-17.

Swank, V. A., W. S. Yoho, K. M. O'Diam, M. L. Eastridge, A. J. Niehaus, and K. M. Daniels. 2013. Jersey calf performance in response to high-protein, high-fat liquid feeds with varied fatty acid profiles: Blood metabolites and liver gene expression. J. Dairy Sci. 96:3845-3856

Tan, D. W., and N. Barker. 2014. Intestinal stem cells and their defining niche. Curr. Top. Dev. Biol. 107:77-107.

Vandesompele, J., K. De Preter, F. Pattyn, B. Poppe, N. Van Roy, A. De Paepe, and F. Speleman. 2002. Accurate normalization of real-time quantitative RT-PCR data by geometric averaging of multiple internal control genes. Genome Biol. 3:RESEARCH0034.

Velayudhan, B. T., K. M. Daniels, D. P. Horrell, S. R. Hill, M. L. McGilliard, B. A. Corl, H. Jiang, and R. M. Akers. 2008. Developmental histology, segmental expression, and nutritional regulation of somatotropic axis genes in small intestine of preweaned dairy heifers. J. Dairy Sci. 91:3343-3352.

Yohe, T. T., K. M. O'Diam, and K. M. Daniels. 2015. Growth, ruminal measurements, and health characteristics of Holstein bull calves fed an Aspergillus oryzae fermentation extract. J. Dairy Sci. 98:6163-6175.

Zouboulis, C. C., J. Adjaye, H. Akamatsu, G. Moe-Behrens, and C. Niemann. 2008. Human skin stem cells and the ageing process. Exp. Gerontol. 43:986-997. 